\title{
The Effects of Environmental Mercury Contamination on Wild and Domestic Animals
}

\author{
Louise C Abbott* \\ Department of Veterinary Integrative Biosciences, USA
}

*Corresponding author: Louise C Abbott, Department of Veterinary Integrative Biosciences, USA

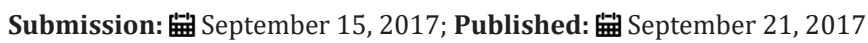

\begin{abstract}
Abbreviations: DDT: Dichloro Diphenyl Trichloroethane; PBDES: Polybrominated Diphenyl Ethers; PAHs: Polycyclic Aromatic Hydrocarbons; PCBs: Polychlorinated Biphenyls; UNEP: United Nations Environment Programme
\end{abstract}

\section{Opinion}

Any substance that is toxic to humans is usually toxic to wild and domestic animals as well. Different levels of sensitivity and degrees of exposure between humans and animals may exist for toxicants, but similarities of effect are generally more common than differences. Of particular concern to both human and animal populations are persistent contaminants that do not break down readily in the environment and tend to bio accumulate. The many persistent toxic substances found contaminating our environment include Polychlorinated Biphenyls (PCBs), Polybrominated Diphenyl Ethers (PBDES), polycyclic aromatic hydrocarbons (PAHs), dioxins, dichlorodiphenyltrichloroethane (DDT) and heavy metals, such as lead, cadmium, nickel, and mercury [1-5]. Any one of these contaminants is worthy of an entire commentary. This article will focus on the effects of environmental mercury contamination on animal populations, both wild and domestic.

Environmental contamination from mercury is ubiquitous on our planet [6]. A 2013 report from the United Nations Environment Programme (UNEP) estimated the total, annual emission of mercury to be in the range of 5,000 to 8,000 metric tons per year [6]. Emissions include anthropogenic sources (such as coalburning power plants and gold mining), natural geological sources (such as volcanoes) and re-emission or exposure of mercury due to disturbance of soils and sediments containing mercury [6]. Mercury is highly toxic to the developing nervous system and organic mercury, in the form of methyl mercury, is the primary form of mercury to which humans and animals are exposed. Due its lipophilicity, methylmercury is easily absorbed into the body and distributed widely where multiple organs, including the central nervous system, take up mercury [7]. However, even though mercury is well known to be highly toxic, little is still known about the fate of mercury in the bodies of animals [8]. Among studies that do examine mercury levels in non-laboratory animals, many have examined exposures of wild and domestic animals to mercury that could serve as sentinels for human exposure [8-10]. Animals including wild mink [9], vampire bats [10], hares and rabbits [11], wild seals and bears [12], wild birds [13], domestic cattle and domestic fowl [14-16], and domestic dogs [17] are some of the animals that have been assessed for their mercury "body load" over the past 20 to 25 years.

These studies provide several points to consider concerning levels of mercury in animal populations. Vampire bats found in South America that fed more on domestic animals presented higher mercury loads than bats that fed on wild animals, suggesting that domestic animals were exposed to higher levels of mercury [10]. Studies of mercury exposures in cattle in Spain showed similar levels to those reported in cattle from non-polluted areas in other countries [16]. However, domestic cattle and fowl raised in areas with high mercury contamination such as gold mining areas have much higher levels of mercury in their tissues and organs compared to animals from non-mining regions [14]. Environmental pollution associated with gold mining-occurs, not only in South America, but in Canada, the United States, Africa, China, the Philippines and Siberia [18].

Many studies of the effects of mercury contamination on animal populations have focused on marine mammals such as seals and polar bears and marine birds. This article cannot discuss all of this literature, which goes back more than 50 years. Several more recent reviews indicate that exposure to mercury can suppress immune function in marine mammals [11,19], result in neurochemical changes in the brains of beluga whales and polar bears [20], potentially damage muscle cells in Harbour seals [20] and impair reproduction in arctic mammals and birds [20-23]. One example 
reported for loons in two different studies correlated a 50\% decline in reproductive productivity when prey fish consumed by loons presented whole-body mercury concentrations that exceeded 0.2 micrograms per gram body weight of the fish $[23,24]$. Not all birds are equally sensitive to methylmercury toxicity. The American kestrel, osprey, snowy egret, tri-coloured heron are extremely sensitive to methylmercury toxicity, while other birds such as the Canada goose, laughing gull and double-crested cormorant are much less sensitive [25].

Based on the published literature, significant mercury exposures among dogs and cats appear to be rare. A study published in Canada reported very few cases of mercury toxicosis for dogs and cats compared to wild, fish eating birds [26]. However, these studies only report mercury levels in animals that are suspected of having metal toxicosis. In this same study, birds, especially raptors consuming fish contaminated with methylmercury showed many more cases with toxic levels of mercury [26]. Mercury is not routinely sampled in domestic animal populations, so it is not possible to know if subclinical exposures are routinely occurring. One survey of mercury exposures to domestic dogs in Spain indicated that mercury tissue concentrations were three times higher in dogs from urban areas compared to dogs from rural areas [17]. In 2005, several studies reported that contaminants, including mercury, did not cause widespread adverse effects on the health of Canadian arctic wildlife, with the possible exception of polar bears and caribou $[27,28]$. Then what about the present? Is exposure to mercury contamination increasing in animal populations? The short answer is yes and no. Some animal populations have exhibited significant increases in their body burden of mercury and others have not changed, or have even decreased [29]. We also cannot determine whether the most recent increases in mercury body burden observed in some animal populations are due to increased anthropogenic activity or possibility due to environmental changes, e.g., climate warming [29]. Current changes in climate are predicted to increase disease risk in arctic animal populations and perhaps other populations as well [21], which could make animals more susceptible to mercury toxicity.

\section{Conclusion}

In conclusion, what is currently known about mercury exposure on the animal population, both domestic and wild, is not sufficient to say with confidence that mercury exposure has significant adverse health effects on a large number of species [20]. It appears to be the case that the Beluga whale, polar bears, and a number of species of primarily arctic birds, do exhibit specific health defects including decreased immune function, altered neuronal function and decreased reproductive capabilities. It also is the case that domestic animals, other than isolated cases of acute mercury toxicity, do not appear to exhibit widespread toxicity due to mercury exposure. However, the general lack of detailed information underlying these observations underscores the explicit need for continued and more detailed study of mercury exposures in animal populations and how mercury exposure, even at subclinical levels, affects the health and reproduction of animals.

\section{References}

1. Swarup D, Patra RC (2005) Environmental pollution and its impact on domestic animals and wildlife. Indian J Anim Sci 75: 231-240.

2. Orazio CE, Chapman DC, May TW, Meadows JC, Walther MJ, et al. (2011) Evaluation of Environmental Contaminants and Elements in Bigheaded Carps of the Missouri River at Easley, Missouri, USA. In: Chapman DC, Hoff MH (Eds.), Am Fish S S74, 199-213.

3. Gueguen M, Amiard JC, Arnich N, Badot PM, Claisse D, et al. (2011) Shellfish and residual chemical contaminants: hazards, monitoring, and health risk assessment along French coasts. Rev Environ Contam Toxicol 213: 55-111.

4. Kucuksezgin F, Pazi I, Yucel-Gier G, Akcali B, Galgani F (2013) Monitoring of heavy metal and organic compound levels along the Eastern Aegean coast with transplanted mussels. Chemosphere 93(8): 1511-1518.

5. Muir DC, Wagemann R, Hargrave BT, Thomas DJ, Peakall DB, et al. (1992) Arctic marine ecosystem contamination. Sci Total Environ 122(1-2): 75134.

6. Futsaeter G, Wilson S (2013) The UNEP Global Mercury Assessment: Sources, Emissions and Transport. E3s Web Conf1, UK.

7. Aschner M, Aschner JL (1990) Mercury neurotoxicity: mechanisms of blood-brain barrier transport. Neurosci Biobehav Rev 14(2): 169-176.

8. Dorea JG, Farina M, Rocha JB (2013) Toxicity of ethylmercury (and Thimerosal): A comparison with methylmercury. J Appl Toxicol 33(8): 700-711.

9. Bowman J, Kidd AG, Martin PA, McDaniel TV, Nituch LA, et al. (2012) Testing for bias in a sentinel species: Contaminants in free-ranging domestic, wild, and hybrid mink. Environ Res 112: 77-82.

10. Becker DJ, Chumchal MM, Bentz AB, Platt SG, Czirjak GA, et al. (2017) Predictors and immunological correlates of sublethal mercury exposure in vampire bats. Roy Soc Open Sci 4(4): e170073.

11. Zarski TP, Debski B, Rokicki E, Samek M, Valka J, et al. (1995) Free-Living Animals as Bioindicators of Mercury Pollution. Ekol Bratislava 14: 113117.

12. Woshner VM, O’Hara TM, Bratton GR, Beasley VR (2001) Concentrations and interactions of selected essential and non-essential elements in ringed seals and polar bears of arctic Alaska. J Wildlife Dis 37(4): 711721

13. Bekhit AE, Al-Amer S, Gooneratne R, Mason SL, Osman KA, et al. (2011) Concentrations of trace elementals and organochlorines in Mutton bird (Puffinus griseus). Ecotox Environ Safe 74: 1742-1746.

14. Chibunda RT, Janssen CR (2009) Mercury residues in free-grazing cattle and domestic fowl form the artisanal gold mining area of Geita district, Tanzania. Food Addit Contam A 26(11): 1482-1487.

15. Adei E, Forson-Adaboh K (2008) Toxic (Pb, Cd, Hg) and essential (Fe, Cu, $\mathrm{Zn}, \mathrm{Mn}$ ) metal content of liver tissue of some domestic and bush animals in Ghana. Food Addit Contam B 1(2): 100-105.

16. Alonso ML, Benedito JL, Miranda M, Castillo C, Hernandez J, et al. (2003) Mercury concentrations in cattle from NW Spain. Sci Total Environ 302(1-3): 93-100.

17. Lopez-Alonso M, Miranda M, Garcia-Partida P, Cantero F, Hernandez J (2007) Use of dogs as indicators of metal exposure in rural and urban habitats in NW Spain. Sci Total Environ 372(2-3): 668-675.

18. Eisler R (2004) Mercury hazards from gold mining to humans, plants, and animals. Rev Environ Contam Toxicol 181: 139-198.

19. Desforges JP, Sonne C, Levin M, Siebert U, De Guise S, et al. (2016) Immunotoxic effects of environmental pollutants in marine mammals. Environ Int 86: 126-139.

20. Scheuhammer A, Braune B, Chan HM, Frouin H, Krey A, et al. (2015) Recent progress on our understanding of the biological effects of 
mercury in fish and wildlife in the Canadian Arctic. Sci Total Environ 509-510: 91-103.

21. Dudley JP, Hoberg EP, Jenkins EJ, Parkinson AJ (2015) Climate Change in the North American Arctic: A One Health Perspective. Ecohealth 12(4): 713-725.

22. Scheuhammer AM, Basu N, Burgess NM, Elliott JE, Campbell GD, et al (2008) Relationships among mercury, selenium, and neurochemical parameters in common loons (Gavia immer) and bald eagles (Haliaeetus leucocephalus). Ecotoxicology 17(2): 93-101.

23. Evers DC, Savoy LJ, DeSorbo CR, Yates DE, Hanson W, et al. (2008) Adverse effects from environmental mercury loads on breeding common loons. Ecotoxicology 17(2): 69-81.

24. Burgess NM, Meyer MW (2008) Methylmercury exposure associated with reduced productivity in common loons. Ecotoxicology 17(2): 83-91.

25. Heinz GH, Hoffman DJ, Klimstra JD, Stebbins KR, Kondrad SL, et al. (2009) Species differences in the sensitivity of avian embryos to methylmercury. Arch Environ Contam Toxicol 56(1): 129-138.
26. Hoff B, Boermans HJ, Baird JD (1998) Retrospective study of toxic metal analyses requested at a veterinary diagnostic toxicology laboratory in Ontario (1990-1995). Can Vet J 39(1): 39-43.

27. Fisk AT, de Wit CA, Wayland M, Kuzyk ZZ, Burgess N, et al. (2005) An assessment of the toxicological significance of anthropogenic contaminants in Canadian arctic wildlife. Sci Total Environ 351-352: 57 93.

28. Gamberg M, Braune B, Davey E, Elkin B, Hoekstra PF, et al. (2005) Spatial and temporal trends of contaminants in terrestrial biota from the Canadian Arctic. Sci Total Environ 351-352: 148-164.

29. Braune BM, Outridge PM, Fisk AT, Muir DC, Helm PA, et al. (2005) Persistent organic pollutants and mercury in marine biota of the Canadian Arctic: an overview of spatial and temporal trends. Sci Total Environ 351-352: 4-56. 